\title{
Theoretically nanoscale study on ionization of muscimol nano drug in aqueous solution
}

\author{
Farhoush Kiani, Mehran Abbaszadeh, Mohammad Pousti, Fardad Koohyar* \\ Department of Chemistry, Faculty of Science, Ayatollah Amoli Branch, Islamic Azad University, Amol, Iran
}

\begin{abstract}
In the present work, acid dissociation constant $\left(\mathrm{pK}_{\mathrm{a}}\right)$ values of muscimol derivatives were calculated using the Density Functional Theory (DFT) method. In this regard, free energy values of neutral, protonated and deprotonated species of muscimol were calculated in water at the B3LYP/6-31G(d) basis sets. The hydrogen bond formation of all species had been analyzed using the Tomasi's method. It was revealed that the theoretically calculated $\mathrm{pK}_{\mathrm{a}}$ values were in a good agreement with the existing experimental $\mathrm{pK}_{\mathrm{a}}$ values, which were determined from capillary electrophoresis, potentiometric titration and UV-visible spectrophotometric measurements.
\end{abstract}

Uniterms: Nanodrug. Muscimol. Acid/dissociation constants. Computational chemistry. Density Functional Theory.

\begin{abstract}
No presente trabalho, calculou-se a constante de dissociação do ácido $\left(\mathrm{pK}_{\mathrm{a}}\right)$ dos derivados de muscimol, utilizando-se o método da teoria do funcional de densidade (DFT). Com esse objetivo, calcularam-se os valores das espécies neutra, protonada e desprotonada do muscimol em água em base B3LYP/6-31G(d). A formação da ligação de hidrogênio de todas as espécies foi analisada utilizando o método de Tomasi. Demonstrou-se que os valores de pKa calculados teoricamente estavam em boa concordância com os valores experimentais disponíveis, determinados por eletroforese capilar, titulação potenciométrica e medidas por espectrofotometria UV-visível.
\end{abstract}

Unitermos: Nanofármaco. Muscimol. Ácido/constantes de dissociação. Química computacional. Teoria do funcional de densidade.

\section{INTRODUCTION}

Muscimol ([methylene-3H(n)]-3-hydroxy-5aminoethyl isoxazole) is a strong $\mathrm{GABA}_{\mathrm{A}}$ agonist found naturally in the mushroom (Amanita muscaria). Muscimol is slowly removed by the uptake mechanism, making it more suitable for long-term quantitative studies. Antiepileptic effects were found with epidural pentobarbital and GABA administrations. The antiepileptic effects of subarachnoid lidocaine were shown in epilepsy patients undergoing tissue resection (Michelot, MelendezHowell, 2003; Steardo et al., 1985; Frolund et al., 2002; Chilton, Ott, 1976).

The tendency of a molecule to lose hydarogen atom

\footnotetext{
*Correspondence: Fardad Koohyar. Department of Chemistry, Faculty of Science, Ayatollah Amoli Branch, Amol, Iran, Islamic Azad University. E-mail: FardadKoohyar@yahoo.com
}

as an acidic proton is quantified as $\mathrm{pK}_{\mathrm{a}}$. It is well-known that $\mathrm{pK}_{\mathrm{a}}$ values are important for the development of new compounds with biological activity. It can be due to the relationships between the $\mathrm{pK}_{\mathrm{a}}$ values and those structures, which may help studies in drugs design and also explain the biopharmaceutical properties of substances (Duran, Aydemir, 2012; Barbosa et al., 2001). There are several experimental methods for determining the acidity constants in aqueous solutions for example, conductometry, spectrophotometric, capillary electrophoresis, calorimetric adsorption, potentiometric titration, HPLC, solubility, partition and distribution (Reijenga et al., 2013; Heinze, 1984; Thurlkill et al., 2005; Santos et al., 2010).

In addition to experimental methods, theoretical prediction of the $\mathrm{pKa}$ values has received considerable attention and many studies have been carried out on this topic in recent years (Kelly, Cramer, Truhlar, 2006; Ho, Coote, 2010). 
The DFT methods provide reliable $\mathrm{pK}_{\mathrm{a}}$ values, which help us to better understanding of different effective factors on solvent-solute interactions. This understanding can be essential for interpretation of experimental values in various systems (Topol et al., 2000; Ho, Coote, 2010).

As the $\mathrm{p} K_{\mathrm{a}}$ equals to $\Delta G / 2.303 R T$ (where $\Delta G$ is a free energy change of the dissociation reaction either in a gas or solution) acidity of a compound can be determined by its $\Delta G$ value (Tosso et al., 2009).

In summary, the aim of this study was to calculate $\mathrm{pK}_{\mathrm{a}}$ values of muscimol using the DFT method and the results were compared with those of existed experimental values. At first, all structures were optimized using the B3LYP/6-31G(d) level of theory. The solvent effect was simulated using integral equation formalism of the polarizable continuum model (IEF-PCM). Also explicit solvent were used in our calculation to study hydrogen bond formation. Table II shows that there is a good agreement between experimental and calculated $\mathrm{pK}_{\mathrm{a}}$ values by considering their RD.

\section{COMPUTATIONAL METHODS}

All calculations about properties of muscimol molecule (Figure 1) were carried out, on a Pentium 4 computer, using the Gaussian_09 version (Frisch et al., 2009). The DFT-B3LYP/6-31G(d)/SMD method were applied on all structures.

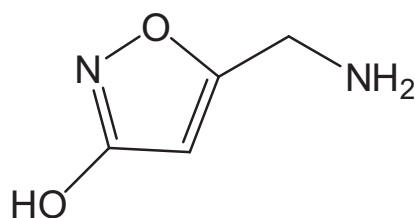

FIGURE 1 - Planar structure of muscimol molecule (The figure was generated using the Spartan 08 program $^{\mathrm{a}}$.) a: Young, 2001; Spartan, 2008

To evaluate the conformational behaviour of these systems in solvent-solution phase, calculations were performed using the solvation model density (SMD) a method of implicit solvation model (Marenich, Cramer, Truhlar, 2009). The SMD uses the integral equation formalism of the polarizable continuum model (IEF-PCM) (Scalmani, Frisch, 2010; Cossi et al., 1998; Mennucci, Cances, Tomasi, 1997; Ribeiro et al., 2010) with a parameterized set of atomic radii, to calculate the bulk electrostatic energy contribution.

The model calculates short-range interaction energies between solvent and solute using a modified solvent-accessible surface area which incorporates parameters for atomic and molecular surface tensions and hydrogen-bond acidity and basicity, which has been proven to be an effective tool to investigate on a variety of solution phase physicochemical properties. Solvation of selected species was finally considered in terms of the intermolecular hydrogen bonds (IHBs) (see Table I and Figure 2) (Remko, 2010).

TABLE I - Calculated free energies $\left(\mathrm{G}^{0}{ }_{\text {sol }}\right)$ using the solvation model density (SMD) method at the B3LYP/6-31G(d) level of theory for cationic $\left(\mathrm{H}_{2} \mathrm{~L}^{+}\right)$, neutral $(\mathrm{HL})$, and anionic $\left(\mathrm{L}^{-}\right)$species of muscimol molecule with or without water clusters

\begin{tabular}{lccc}
\hline $\mathrm{N}$ & $\begin{array}{c}\text { Solvated } \\
\text { species }\end{array}$ & $\begin{array}{c}\mathrm{G}_{\text {sol }}^{\circ} \\
(\text { Hartree })\end{array}$ & $\begin{array}{c}\mathrm{G}_{\text {sol }}^{\circ} / \text { molecule } \\
\left(\mathrm{kcal} \cdot \mathrm{mol}^{-1}\right)\end{array}$ \\
\hline 1 & $\mathrm{H}_{2} \mathrm{~L}^{+}\left(\mathrm{H}_{2} \mathrm{O}\right)$ & -493.397 & -309611.173 \\
1 & $\mathrm{HL}\left(\mathrm{H}_{2} \mathrm{O}\right)$ & -492.923 & -309313.670 \\
1 & $\mathrm{~L}^{-}\left(\mathrm{H}_{2} \mathrm{O}\right)$ & -492.453 & -309018.945 \\
2 & $\left.\mathrm{HL}^{-} \mathrm{H}_{2} \mathrm{O}\right)_{2}$ & -569.353 & -357274.383 \\
2 & $\mathrm{H}_{2} \mathrm{~L}^{+}\left(\mathrm{H}_{2} \mathrm{O}\right)_{2}$ & -569.827 & -357572.034 \\
2 & $\mathrm{~L}^{-}\left(\mathrm{H}_{2} \mathrm{O}\right)_{2}$ & -568.891 & -356984.479 \\
3 & $\mathrm{~L}^{-}\left(\mathrm{H}_{2} \mathrm{O}\right)_{3}$ & -645.322 & -404945.445 \\
3 & $\mathrm{H}_{2} \mathrm{~L}^{+}\left(\mathrm{H}_{2} \mathrm{O}\right)_{3}$ & -646.262 & -405535.288 \\
3 & $\mathrm{HL}^{-}\left(\mathrm{H}_{2} \mathrm{O}\right)_{3}$ & -645.805 & -405248.526 \\
0 & $\mathrm{HL}_{2}$ & -416.485 & -261348.477 \\
0 & $\mathrm{H}_{2} \mathrm{~L}^{+}$ & -416.959 & -261645.854 \\
0 & $\mathrm{~L}^{-}$ & -416.015 & -261053.431 \\
1 & $\mathrm{H}_{2} \mathrm{O}$ & -76.437 & -47965.159 \\
2 & $\left(\mathrm{H}_{2} \mathrm{O}\right)_{2}$ & -152.880 & -95933.519 \\
3 & $\left(\mathrm{H}_{2} \mathrm{O}\right)_{3}$ & -229.321 & -143901.311 \\
0 & $\mathrm{OH}^{-}$ & -75.949 & -47658.671 \\
1 & $\mathrm{OH}^{-}\left(\mathrm{H}_{2} \mathrm{O}\right)$ & -152.397 & -95630.633 \\
2 & $\mathrm{OH}^{-}\left(\mathrm{H}_{2} \mathrm{O}\right)_{2}$ & -228.845 & -143602.626 \\
3 & $\mathrm{OH}^{-}\left(\mathrm{H}_{2} \mathrm{O}\right)_{3}$ & -305.226 & -191531.917 \\
\hline
\end{tabular}

$\mathrm{N}$ : total number of solvation water molecules; $\left(\mathrm{G}^{0}{ }_{\text {sol }}\right)$ : free energy in solution

\section{RESULTS AND DISCUSSION}

Muscimol naturally have both keto and enol forms (Oster, Harris, 1983). Fully protonated muscimol can lose two acidic hydrogens. The first proton can be lost from $\mathrm{OH}$ group and the second one from $\mathrm{NH}_{2}$ group (Figure 2). In this study, several models of muscimol were investigated by the DFT-B3LYP/6-31G(d)/SMD method. Different reactions including cationic, neutral, and anionic species were tested and some of them were finally chosen for the studied system. Table II shows the selected reactions 


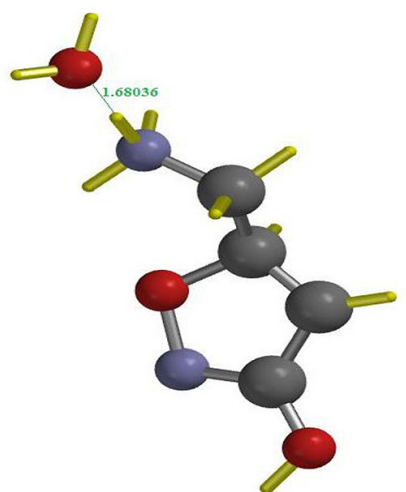

$\mathrm{H}_{2} \mathrm{~L}^{+}\left(\mathrm{H}_{2} \mathrm{O}\right)$

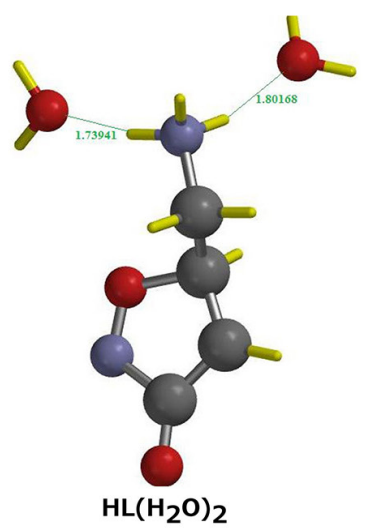

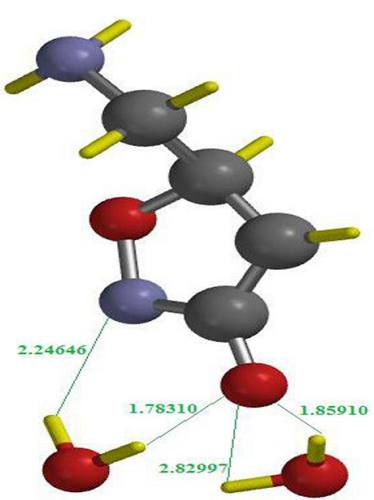

$\mathrm{L}^{-}\left(\mathrm{H}_{2} \mathrm{O}\right)_{2}$

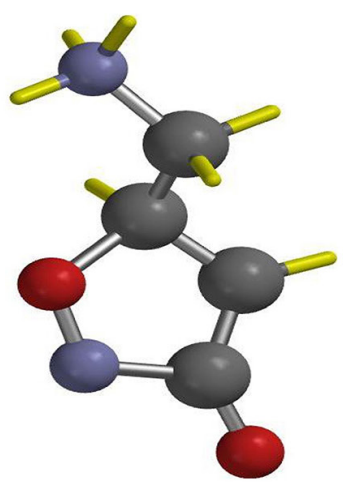

HL
FIGURE 2 - Optimized molecular structure for muscimol clusters in presence of water molecules using the solvation model density (SMD) method. The most important hydrogen bond distances are shown in figures (green lines) and its distance are in angstrom (red number). The figures were generated using the Spartan 08 program $^{\mathrm{a}}$. The carbon atoms are represented by gray circles, oxygen, red; nitrogen, purple and hydrogen atoms, yellow sticks. a: Young, 2001; Spartan, 2008.

and calculated $\mathrm{pK}_{\mathrm{a}}$ values of muscimol together with the relative deviations (RD) for $\mathrm{pK}_{\mathrm{a}}$ which can be obtained from the following equation:

$R D=\left|\frac{p K a_{(\text {calculated })}-p K a_{(\text {experimental })}}{p K a_{(\text {experimental })}}\right|$

(Equation 1)
The very low values of RD (for $\mathrm{pK}_{\mathrm{a}}$ ) (see Table II) show that there is a good agreement between experimental and calculated values of $\mathrm{pK}_{\mathrm{a}}$ for muscimol .

\section{First Ionization Constant of Muscimol}

It was selected that in alkaline solutions muscimol suffers a total neutralization as follows:

$\mathrm{H}_{2} \mathrm{~L}^{+}\left(\mathrm{H}_{2} \mathrm{O}\right)+\mathrm{OH}^{-}\left(\mathrm{H}_{2} \mathrm{O}\right)_{3} \rightleftarrows \mathrm{HL}\left(\mathrm{H}_{2} \mathrm{O}\right)_{2}+3 \mathrm{H}_{2} \mathrm{O}$ (Equation 2)

In the above reaction, $\mathrm{H}_{2} \mathrm{~L}^{+}\left(\mathrm{H}_{2} \mathrm{O}\right)$ is the cluster of a cationic muscimol with one molecule of water, and $\mathrm{HL}\left(\mathrm{H}_{2} \mathrm{O}\right)_{2}$ represents a cluster of neutral muscimol with two water molecules. The above reaction was used to determine value of the first ionization constant of muscimol in water. Table II shows the calculated $\mathrm{pK}_{\mathrm{a}}$ values and the difference of free energy between $\left[\mathrm{HL}\left(\mathrm{H}_{2} \mathrm{O}\right)_{2}, 3 \mathrm{H}_{2} \mathrm{O}\right]$ and $\left[\mathrm{H}_{2} \mathrm{~L}^{+}\left(\mathrm{H}_{2} \mathrm{O}\right), \mathrm{OH}^{-}\left(\mathrm{H}_{2} \mathrm{O}\right)_{3}\right]$ according to Equation 2 obtained at the B3LYP/6-31G(d)/SMD level of theory.

\section{Second Ionization Constant of Muscimol}

It is selected that the neutral HL suffers a reaction of partial neutralization as follows:

$\mathrm{HL}+\mathrm{OH}^{-}\left(\mathrm{H}_{2} \mathrm{O}\right)_{3} \rightleftarrows \mathrm{L}^{-}\left(\mathrm{H}_{2} \mathrm{O}\right)_{2}+2 \mathrm{H}_{2} \mathrm{O}$

(Equation 3)

In the above reaction, $\mathrm{HL}$ and $\mathrm{L}-\left(\mathrm{H}_{2} \mathrm{O}\right)_{2}$ represent the neutral and anionic cluster forms of muscimol, respectively. The above reaction was used to determine value of the second ionization constant of muscimol in water. Table II shows the calculated $\mathrm{pK}_{\mathrm{a}}$ and the difference of free energy between $\left[\mathrm{L}^{-}\left(\mathrm{H}_{2} \mathrm{O}\right)_{2}, 2 \mathrm{H}_{2} \mathrm{O}\right]$ and $\left[\mathrm{HL}, \mathrm{OH}^{-}\right.$ $\left(\mathrm{H}_{2} \mathrm{O}\right)_{3}$ ] according to Equation 3 obtained at the B3LYP/6$31 \mathrm{G}(\mathrm{d})$ level of theory with solvation model density (SMD) method in water.

The $\mathrm{pK}_{\mathrm{a}}$ determination method was previously described, and its values for muscimol were used in this work (Krogsgaard-Larsen et al., 1980; Brehm et al., 1997). These values are listed in Table II together with the calculated values using the solvation model density

TABLE II - Values of the $\Delta \mathrm{G}, \mathrm{pK}_{\mathrm{a}}$, and relative deviations (RD) of $\mathrm{pK}_{\mathrm{a}}$ for muscimol obtained using the B3LYP/6-31G(d)/SMD

\begin{tabular}{lcccc}
\hline Selected equations & $\begin{array}{c}\Delta \mathrm{G} \text { (Hartree) } \\
\text { calculated }\end{array}$ & $\begin{array}{c}\mathrm{pK}_{\mathrm{a}} \text { (calculated) } \\
\text { this work }\end{array}$ & $\mathrm{pK}_{\mathrm{a}}$ (experimental) & (RD) for $\mathrm{pK}_{\mathrm{a}}$ \\
\hline $\mathrm{H}_{2} \mathrm{~L}^{+}\left(\mathrm{H}_{2} \mathrm{O}\right)+\mathrm{OH}^{-}\left(\mathrm{H}_{2} \mathrm{O}\right)_{3} \rightleftarrows \mathrm{HL}\left(\mathrm{H}_{2} \mathrm{O}\right)_{2}+3 \mathrm{H}_{2} \mathrm{O}$ & -0.052 & 4.734 & $4.8^{\mathrm{a}}$ & 0.0137 \\
$\mathrm{HL}+\mathrm{OH}-\left(\mathrm{H}_{2} \mathrm{O}\right)_{3} \rightleftarrows \mathrm{L}-\left(\mathrm{H}_{2} \mathrm{O}\right)_{2}+2 \mathrm{H}_{2} \mathrm{O}$ & -0.060 & 8.402 & $8.4^{\mathrm{a}}$ & 0.0002 \\
\hline
\end{tabular}

a: (Krogsgaard-Larsen et al., 1980) (Brehm et al., 1997) 
TABLE III - Intermolecular hydrogen bonds (IHBs) information of all muscimol species. Values were taken from Cilli et al. (1996) and Corradi et al. (2000)

\begin{tabular}{lcccc}
\hline Species & Angle & $\begin{array}{c}\text { Value of angle } \\
\left({ }^{\circ}\right.\end{array}$ & $\begin{array}{c}\text { IHBs distance } \\
(\AA)\end{array}$ & Strength of IHB \\
\hline $\mathrm{HL}\left(\mathrm{H}_{2} \mathrm{O}\right)_{2}$ & O-H-N & 168.592 & 1.739 & Moderate \\
& O-H-N & 160.843 & 1.801 & Moderate \\
\hline \multirow{2}{*}{$-\left(\mathrm{H}_{2} \mathrm{O}\right)^{2}$} & O-H-N & 124.947 & 2.246 & Weak \\
& O-H-O & 159.325 & 1.783 & Moderate \\
& C-O-H & 108.373 & 2.829 & Weak \\
\hline $\mathrm{H}_{2} \mathrm{~L}^{+}\left(\mathrm{H}_{2} \mathrm{O}\right)$ & O-H-O & 155.781 & 1.859 & Moderate \\
\hline
\end{tabular}

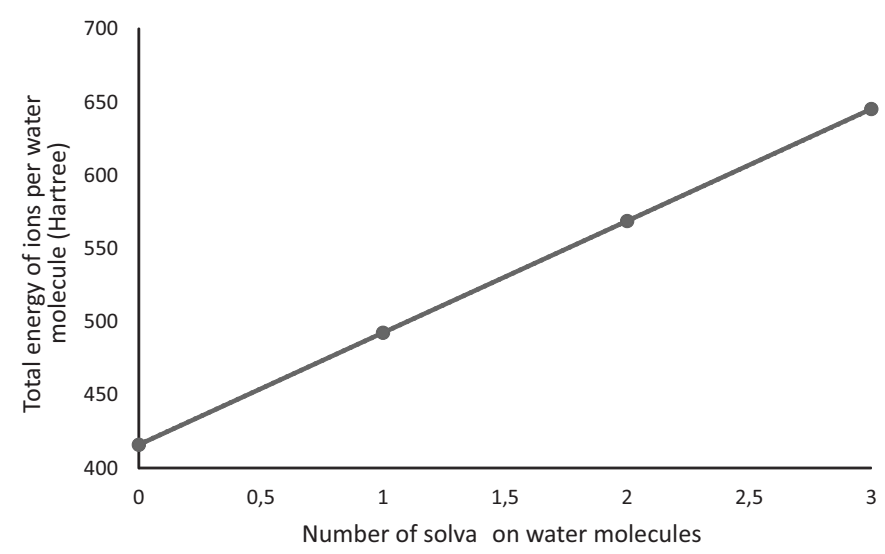

FIGURE 3 - Plot of the total energies (Hartree) of the solvated muscimol per water molecules against the total number of solvation water molecules.

(SMD) method at the B3LYP/6-31G(d) level of theory. The total energies of single and solvated muscimol species (cationic, neutral, and anionic) were calculated in water. Table I summarizes the variations of the free energy $\left(\mathrm{G}_{\text {sol }}^{0}, \mathrm{kcal}^{\mathrm{mol}}{ }^{-1}\right)$ per water molecule as a function of the total number of solvation water molecules for muscimol species. Figure 3 and Table I show the marked decrease of the total energies of ions when the number of solvation molecules increases.

The data of Table III shows that water, exerting its hydrogen bond donor (HBD) capability, forms intermolecular hydrogen bonds (IHBs) with the muscimol molecule. These hydrogen bonds can be classified as strong, moderate, and weak, according to their lengths, angles, and energies (Cilli et al., 1996; Corradi et al., 2000). According to ref (Blanco, Almandoz, Ferretti, 2005), the properties of the moderate hydrogen bonds have the following classification: bond lengths of $\mathrm{H} \cdot \mathrm{B}$ is between (1.5 and 2.2) $\AA$ and the bond angle is $130^{\circ}$ to $180^{\circ}$. For weak hydrogen bonds, the bond length and angle are (2.2 to 3.2$) \AA$ and $90^{\circ}$ to $150^{\circ}$, respectively, and for strong hydrogen bonds are (1.2 to 1.5$) \AA$ and $175^{\circ}$ to $180^{\circ}$, respectively.

Molecular surface and volumes of muscimol's cluster were calculated using solvation model density (SMD) method and are summarized in Table IV.

The volume of clusters may be affected by two main factors. The first factor is the number and volume of atoms or molecules (solute and solvent) which form a cluster. The second factor is the interaction between positive or negative charge of ions (solute) and electrons of solvent molecules. The second factor can be more used in cases that clusters have (approximately) the same number and type of atoms or molecules.

The volume values (V) for the species of muscimol's cluster fall in the order of:

$$
\mathrm{V}\left[\mathrm{L}^{-}\left(\mathrm{H}_{2} \mathrm{O}\right)_{2}\right]>\mathrm{V}\left[\mathrm{HL}\left(\mathrm{H}_{2} \mathrm{O}\right)_{2}\right]>\mathrm{V}\left[\mathrm{H}_{2} \mathrm{~L}^{+}\left(\mathrm{H}_{2} \mathrm{O}\right)\right]>\mathrm{V}[\mathrm{HL}]
$$

As seen in the above order (and Table IV), HL has the minimum volume among four species of muscimol. The first factor is more effective in this case. HL has only one hydrogen atom but other species have hydrogen atom (or atoms) and water molecule (or molecules). The volume of hydrogen atom is less than water molecule.

TABLE IV - Calculated molecular surfaces $\left(\AA^{2}\right)$ and Van der Waals volumes $\left(\AA^{3}\right)$ of different species in equations 2 and 3 for muscimol molecule by using the solvation model density (SMD) method

\begin{tabular}{lcc}
\hline Solvated species & $\begin{array}{c}\text { Molecular surface } \\
\left(\AA^{2}\right)\end{array}$ & $\begin{array}{c}\text { Molecular volume } \\
\left(\AA^{3}\right)\end{array}$ \\
\hline $\mathrm{H}_{2} \mathrm{~L}^{+}\left(\mathrm{H}_{2} \mathrm{O}\right)$ & 171.125 & 135.259 \\
$\mathrm{HL}\left(\mathrm{H}_{2} \mathrm{O}\right)_{2}$ & 179.922 & 147.591 \\
$\mathrm{HL}$ & 162.709 & 115.696 \\
$\mathrm{~L}-\left(\mathrm{H}_{2} \mathrm{O}\right)_{2}$ & 183.417 & 148.247 \\
\hline
\end{tabular}




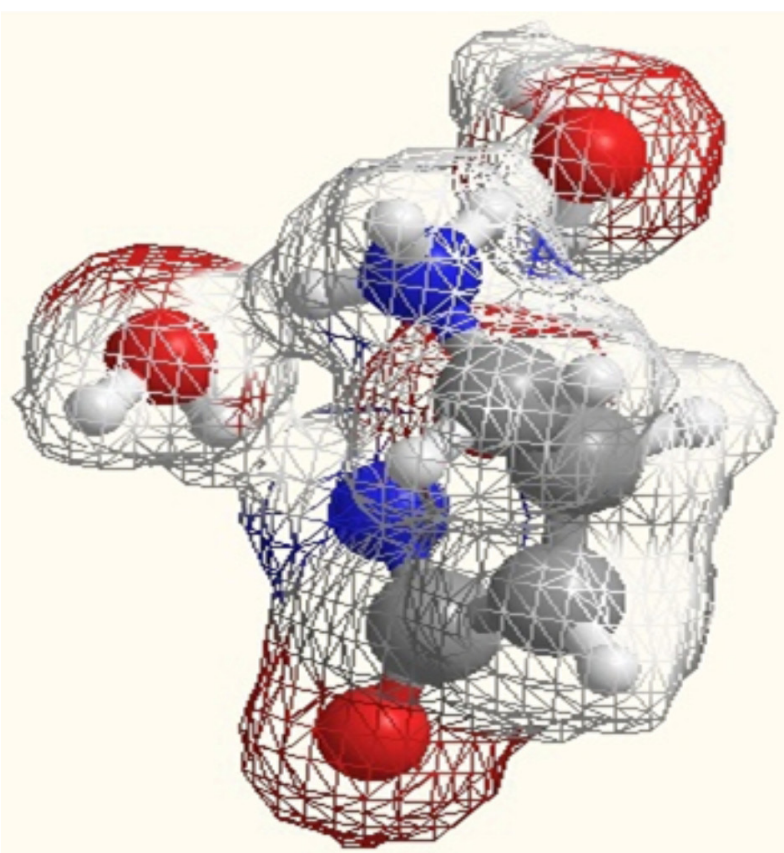

FIGURE 4 - Calculated molecular surface (wireframe) of $\mathrm{HL}\left(\mathrm{H}_{2} \mathrm{O}\right)_{2}$ using the SMD method at the B3LYP/6-31G(d) level of theory. The carbon atoms are represented by gray circles, oxygen, red; nitrogen, purple and hydrogen atoms, white balls.

As an example, the calculated surface of $\mathrm{HL}\left(\mathrm{H}_{2} \mathrm{O}\right)_{2}$ is shown in Figure 4. It is reasonable to observe that molecular volume of the drugs solvated with two water molecules is approximately the sum of the molecular volumes of the species that form it (Figure 4).

\section{CONCLUSION}

The $\mathrm{pK}_{\mathrm{a}}$ values of muscimol (in water) have been predicted using the density functional theory calculation.

In summary, free energies and other molecular parameters were calculated for muscimol molecule, using the B3LYP/6-31G(d)/SMD method for shown species in Tables I, II and III. As shown in Table II, the theoretically calculated $\mathrm{pK}_{\mathrm{a}}$ values are very close to the experimentally calculated $\mathrm{pK}_{\mathrm{a}}$ values. So we can conclude that cluster continuum model, which uses implicit and explicit solvation model, is probably a good way of calculating $\mathrm{pK}_{\mathrm{a}}$ values for biochemical systems.

\section{ACKNOWLEDGMENT}

Thanks are gratefully extended to the Faculty of Chemistry, University of Islamic Azad University, Ayatollah Amoli Branch, for its valuable help with this work.

\section{REFERENCES}

BARBOSA, J.; BARRON, D.; JIMENES LOZANO, E.; SANZ NEBOT, V. Comparison between capillary electrophoresis, liquid chromatography, potentiometric and spectrophotometric techniques for evaluation of $\mathrm{pK}_{\mathrm{a}}$ values of zwitterionic drugs in acetonitrile-water mixtures. Anal. Chim. Acta, v.437, p.309-321, 2001.

BLANCO, S. E.; ALMANDOZ, M. C.; FERRETTI, F. H. Determination of the overlapping $\mathrm{p} K_{\mathrm{a}}$ values of resorcinol using UV-visible spectroscopy and DFT methods. Spectrochim. Acta Part A., v.61, p.93-102, 2005.

BREHM, L.; EBERT, B.; KRISTIANSEN, U.; WAFFORD, K. A.; KEMP, J. A.; KROGSGAARD-LARSEN, P. Structure and pharmacology of 4,5,6,7-tetrahydroisothiazolo[5,4-c] pyridin-3-ol (Thio-THIP), an agonist/antagonist at GABA $_{\mathrm{A}}$ receptors. Eur. J. Med. Chem., v.32, p.357-363, 1997.

CHILTON, W. S.; OTT, J. Toxic metabolites of Amanita panterina, A. cothurnata, A. muscarina, and other Amanita species. Lloydia, v.39, p.150-157, 1976.

CILLI, E. M.; OLIVEIRA, E.; MARCHETTO, R.; NAKAIE, C. R. Correlation between solvation of peptide-resins and solvent properties. J. Org. Chem., v.61, p.8992-9000, 1996.

CORRADI, E.; MEILlE, S. V.; MESSINA, M. T.; METRANGOLO, P.; RESNATI, G. Halogen bonding versus hydrogen bonding in driving self-assembly processes. Angew. Chem. Int. Ed., v.112, p.1852-1856, 2000.

COSSI, M.; BARONE, V.; MENNUCCI, B.; TOMASI, J. $A b$ initio study of ionic solutions by a polarizable continuum dielectric model. J. Chem. Phys. Lett., v.286, p.253-260, 1998.

DURAN, M.; AYDEMIR, S. Ab initio studies on acidity and tautomeric equilibrium constants of some benzoxa-, benzothia-, benzoselena-zolinone derivatives. Comput. Theor. Chem., v.989, p.69-74, 2012.

FROLUND, B.; EBERT, B.; KRISTIANSEN, U.; LILJEFORS, T.; KROGSGAARD-LARSEN, P. GABA-A receptor ligands and their therapeutic potentials. Curr. Top. Med. Chem., v.2, p.817-832, 2002. 
FRISCH, M. J., TRUCKS, G. W.; SCHLEGEL, H. B.; SCUSERIA, G. E. ROBB, M. A.; CHEESEMAN, J. R.; SCALMANI, G.; BARONE, V.; MENNUCCI, B.; PETERSSON, G. A.; NAKATSUJI, H.; CARICATO, M.; LI, X.; HRATCHINA, H. P.; IZMAYLOV, A. F.; BLOINO, J.; ZHENG, G.; SONNENBERG, J. L.; HADA, M.; EHARA, M.; TOYOTA, K.; FUKUDA, R.; HASEGAWA, J.; ISHIDA, M.; NAKAJIMA, T.; HONDA, Y.; KITAO, O.; NAKAI, H.; VREVEN, T.; MONTGOMERY, JR., J. A. J. E. P.; OGLIARO, F.; BEARPARK, M.; HEYD, J. J.; BROTHERS, E.; KUDIN, K. N.; STAROVEROV, V. N.; KOBAYASHI, R.; NORMAND, J.; RAGHAVACHARI, K., RENDELL, A., BURANT, J. C., IYENGAR, S. S., TOMASI, J., COSSI, M.; REGA, N.; MILLAM, J. M.; KLENE, M.; KNOX, J. E.; CROSS, J. B.; BAKKEN, V.; ADAMO, C.; JARAMILLO, J.; GOMPERTS, R.; STRATMANN, R. E.; YAZYEV, O.; AUSTIN, A. J.; CAMMI, R.; POMELLI, C.; OCHTERSKI, J. W.; MARTIN, R. L.; MOROKUMA, K.; ZAKRZEWSKI, V. G.; VOTH, G. A.; SALVADOR, P.; DANNENBERG, J. J.; DAPPRICH, S.; DANIELS, A. D.; FARKAS, O.; FORESMAN, J. B.; ORTIZ, J. V.; CIOSLOWSKI, J.; FOX, D. J. Gaussian 09, Revision A.01, Gaussian, Inc., Wallingford CT, 2009.

HEINZE, J. Cyclic voltammetry-"Electrochemical spectroscopy”. Angew. Chem. Int. Ed., v.23, p.831-847, 1984.

HO, J.; COOTE, M.L. $\mathrm{pK}_{\mathrm{a}}$ calculation of some biologically important carbon acids - an Assessment of contemporary theoretical procedures. J. Chem. Theor. Comput., v.5, p.295306, 2009.

HO, J.; COOTE, M. L. A universal approach for continuum solvent $\mathrm{pK}_{\mathrm{a}}$ calculations: are we there yet? Theor. Chem. Accounts, v.125, p.3-21, 2010.

KELLY, C. P.; CRAMER, C. J.; TRUHLAR, D. G. Adding explicit solvent molecules to continuum solvent calculations for the calculation of aqueous acid dissociation constants. J. Phys. Chem. A., v.110, p.2493-2499, 2006.

KROGSGAARD-LARSEN, P.; HONORE, T.; HANSEN, J.J.; CURTIS, D.R.; LODGE, D. New class of glutamate agonist structurallly related to ibotecnic acid. Nature, v.284, p.6466, 1980.
MARENICH, A. V.; CRAMER, C. J.; TRUHLAR, D. G. Universal solvation model based on solute electron density and on a continuum model of the solvent defined by the bulk dielectric constant and atomic surface tensions. J. Phys. Chem. B., v.113, p.6378-6396, 2009.

MENNUCCI, B.; CANCES, E.; TOMASI, J. Evaluation of solvent effects in isotropic and anisotropic dielectrics and in ionic solutions with a unified integral equation method: theoretical bases, computational implementation, and numerical applications. J. Phys. Chem. B., v.101, p.10506$10517,1997$.

MICHELOT, D.; MELENDEZ-HOWELL. L. M. Amanita muscaria: chemistry, biology, toxicology, and ethnomycology. Mycol. Res., v.107, p.131-146, 2003.

OSTER, T. A.; HARRIS, T. M. Generation and reactions of the dianion of 3-hydroxy-5-methylisoxazole, a convenient beta-oxo amide synthon. Total synthesis of muscimol. $J$. Org. Chem., v.48, p.4307-4311, 1983.

REIJENGA, J.; VAN HOOF, A.; VAN LOON, A.; TEUNISSEN, B. Development of methods for the determination of $\mathrm{pK}_{\mathrm{a}}$ values. Anal. Chem. Insights, v.8, p.53-71, 2013.

REMKO, M. Molecular structure, $\mathrm{p} K_{a}$, lipophilicity, solubility and absorption of biologically active aromatic and heterocyclic sulfonamides. J. Mol. Struc.: THEOCHEM., v.944, p.34-42, 2010.

RIBEIRO, R. F.; MARENICH, A. V.; CRAMER, C. J.; TRUHLAR, D. G. Prediction of SAMPL 2 aqueous solvation free energies and tautomeric ratios using the SM8, SM8AD, and SMD solvation models. J. ComputerAided. Mol. Design, v.24, p.317-333, 2010.

SANTOS, T. A. D.; COSTA, D. O.; PITA, S.; SEMAAN, F. $\mathrm{S}$. Potentiometric and conductimetric studies of chemical equilibria for pyridoxine hydrochloride in aqueous solutions: simple experimental determination of $\mathrm{pKa}$ values and analytical applications to pharmaceutical analysis. Eclet. Quím., v.35, p.81-86, 2010.

SCALMANI, G.; FRISCH, M. J. Continuous surface charge polarizable continuum models of solvation. I. General formalism. J. Chem. Phys., v.132, p.114110-15, 2010.

Spartan. Wavefunction, Inc. Available at: $<$ http://www.wavefun. com/index.html>. Accessed on: Dec 2013. 
STEARDO, L.; IOVINO, M.; MONTELEONE, P.; AGRUSTA, M.; ORIO, F. Evidence for a GABAergic control of the exercise-induced rise in GH in man. Eur. J. Clin. Pharmacol., v.28, p.607-609, 1985.

THURLKILL, R. L.; CROSS, D. A.; SCHOLTS, J. M.; PACE, C. N. The pKa of fentanyl varies with temperature: implications for acid-base management during extremes of body temperature. J. Cardiothorac. Vas. Anesth., v.19, p.759-762, 2005.

TOPOL, I. A.; BURT, S. K.; RASHIN, A. A.; ERICKSON, J. W. Calculation of substituent effects on $\mathrm{pK}_{\mathrm{a}}$ values for pyrone and dihydropyrone inhibitors of HIV-1 protease. J. Phys. Chem. A., v.104, p.866-872, 2000.
TOSSO, R. D.; ZAMORA, M. A.; SURVIRE, F. D.; ENRIZ, R. D. Ab initio and DFT study of the conformational energy hypersurface of cyclic gly-gly-gly. J. Phys. Chem. A., v.113, p.10818-10825, 2009.

YOUNG, D. Computational Chemistry: a practical guide for applying techniques to reall world problems. London: John Wiley \& Sons, 2001. 408 p. (Appendix A. A.1.6 pg 330, SPARTAN).

Received for publication on $02^{\text {nd }}$ December 2013 Accepted for publication on $26^{\text {th }}$ November 2014 
